OPEN ACCESS

Edited by:

Maria Graca Rasteiro, University of Coimbra, Portugal

Reviewed by:

Nito Angelo Debacher,

Federal University of Santa

Catarina, Brazil

Licínio Manuel Gando-Ferreira,

University of Coimbra, Portugal

*Correspondence:

Rabelani Mudzielwana mudzrabe@gmail.com

Specialty section:

This article was submitted to Green and Sustainable Chemistry,

a section of the journal

Frontiers in Chemistry

Received: 13 August 2019 Accepted: 16 December 2019

Published: 15 January 2020

Citation:

Mudzie/wana R, Gitari MW and Ndungu P (2020) Enhanced As(III) and As(V) Adsorption From Aqueous

Solution by a Clay Based Hybrid

Sorbent. Front. Chem. 7:913

doi: 10.3389/fchem.2019.00913

\section{Enhanced As(III) and As(V) Adsorption From Aqueous Solution by a Clay Based Hybrid Sorbent}

\author{
Rabelani Mudzielwana ${ }^{1 *}$, Mugera Wilson Gitari ${ }^{1}$ and Patrick Ndungu ${ }^{2}$ \\ ${ }^{1}$ Environmental Remediation and Nano Science, Department of Ecology and Resource Management, University of Venda, \\ Thohoyandou, South Africa, ${ }^{2}$ Department of Applied Chemistry, University of Johannesburg, Johannesburg, South Africa
}

In this study, a hybrid arsenic adsorbent was synthesized through intercalation inorganic and organic surfactant cations onto kaolin clay interlayers. The synthesized adsorbent was characterized X-ray fluorescence (XRF), Fourier Transform Infrared spectroscopy (FTIR), Scanning electron microscopy (SEM), and Brunauer-Emmett-Teller (BET). Batch studies were conducted to determine As(III) and As(V) removal capacity of hybrid sorbent synthesized. It is found that $\mathrm{As}(\mathrm{III})$ removal is optimum at $\mathrm{pH}$ range of 4-6 while $\mathrm{As}(\mathrm{V})$ removal is optimum at $\mathrm{pH}$ range 4-8. The data for adsorption kinetics fitted to pseudo second order model implying that adsorption of $A s(I I I)$ and $A s(V)$ is chemisorption. The isotherm studies showed a better fit to Langmuir isotherm model indicating that adsorption of both $\mathrm{As}(\mathrm{III})$ and $\mathrm{As}(\mathrm{V})$ occurred on a mono-layered surface. The maximum adsorption $\mathrm{As}(\mathrm{III})$ and $\mathrm{As}(\mathrm{V})$ capacity at room temperature as determined by Langmuir model were found to be 7.99 and $7.32 \mathrm{mg} / \mathrm{g}$, respectively. Thermodynamic parameters, $\Delta \mathrm{G}^{\circ}$ and $\Delta \mathrm{H}^{\circ}$ were found to be negative indicating that adsorption process occurred spontaneously and exothermic. Inorgano-organo modified kaolin clay was successfully regenerated for up 7 adsorption-regeneration cycles using $0.01 \mathrm{M} \mathrm{HCl}$ as regenerant. This study concluded that hybrid sorbent synthesized in this study is suitable for arsenic removal from groundwater.

Keywords: arsenic removal, clay based hybrid sorbent, adsorption kinetics, adsorption isotherms, thermodynamics

\section{INTRODUCTION}

Arsenic is a toxic element that is widely distributed in different matrixes within the natural environment. In groundwater, arsenic is mainly introduced through weathering of arsenic bearing rock minerals such as; arsenopyrite ( $\mathrm{FeAsS}$ ), realgar (AsS), cobaltite (CoAsS), and scorodite $\left(\mathrm{FeAsO}_{4} \cdot 2 \mathrm{H}_{2} \mathrm{O}\right)($ Smedley and Kinniburgh, 2002). Other anthropogenic activities such as; mining, burning of fossil fuel and agriculture also result in groundwater contamination by arsenic (Zhang et al., 2017). Arsenic occurs in both organic and inorganic form. The inorganic form of arsenic is dominantly found in water and it exist as arsenite $[\mathrm{As}(\mathrm{III}))$ and arsenate $(\mathrm{As}(\mathrm{V})]$ depending on oxidation state. The arsenate is found in oxidizing conditions while the arsenite is found under reducing conditions (Duker et al., 2005). Arsenite is highly toxic and mobile compared to arsenate (Qi et al., 2015).

Long term exposure to arsenic through drinking water is linked to arsenicosis disease which is manifested by different types of cancer, hypertension, neurological complications and 
cardiovascular disease (Bhowmick et al., 2018). More than 200 million cases of these diseases has been reported in countries like India, Bangladesh, Argentina, Taiwan, Mexico, and China where elevated concentration of arsenic has been reported (Bardach et al., 2015; Ghosh et al., 2019). The World Health Organization (WHO) has set the provisional guideline for arsenic in drinking water at $10 \mu \mathrm{g} / \mathrm{L}(\mathrm{WHO}, 2017)$. Technologies such as precipitation and coagulation, oxidation, reverse osmosis, ion-exchange, and adsorption are generally used for removal of arsenic to acceptable levels (Ghosh et al., 2019). Amongst these technologies, adsorption is widely preferred due to its cost effectiveness, ease of operation and higher efficiency (Qi et al., 2015). Materials such as activated alumina, activated carbon, graphene oxides, clay soils, bone char, and granular ferric hydroxides have been evaluated for their efficiency toward arsenic removal. Although these materials have shown good potential for use in arsenic removal, not all of them can be regenerated effectively and some operate at a narrow $\mathrm{pH}$ level which limit their application.

Clay and their minerals are used in removal of arsenic and other contaminants from water because of their properties such as chemical and mechanical stability, higher cation/anion capacity, and higher surface area (Bhattacharyya and Gupta, 2008). Furthermore, their sorption efficiency may be enhanced through modification by high density inorganic polycations and organic surfactants (Gitari and Mudzielwana, 2018). Mishra and Mahato (2016) reported enhanced arsenic adsorption efficiency of bentonite clay modified using iron and manganese oxides while octadecyl benzyl dimethyl ammonium modified bentonite prepared by Su et al. (2011) also showed better As(III) and As(V) adsorption capacity as compared to bare bentonite. Inorganoorgano modified clay mineral has received greater attention from researchers due to their important features such as, possession of two sorption sites which in turn enhances the sorption capacity and also good settling property (Tiwari and Lee, 2012). However, most of the inorgano-organo modified clay adsorbent have shown better sorption efficiency toward As(V) as compared to As(III) which is highly mobile and toxic. Manganese and iron are closely related elements in terms of their chemical properties and occurs concurrently in nature. Manganese oxides are known for their ability to adsorb and oxidize As(III) to As(V) while $\mathrm{Fe}$ oxides have greater potential to adsorb $\mathrm{As}(\mathrm{V})$ species (Zhang et al., 2012). Therefore, the present investigation aims at developing a novel clay based hybrid adsorbent for As(III) and $\mathrm{As}(\mathrm{V})$ removal by modifying kaolin clay mineral with Fe-Mn oxides and HDTMA-Br cationic surfactant.

\section{MATERIALS AND METHODS}

\section{Materials}

Natural kaolin clay was collected from Limpopo, South Africa. $\mathrm{FeCl}_{3}, \mathrm{MnCl}_{2} .4 \mathrm{H}_{2} \mathrm{O}, \mathrm{NaOH}, \mathrm{AsNaO}_{2}$, and $\mathrm{HAsNa}_{2} \mathrm{O}_{4}$ were purchased from Rochelle Chemicals \& Lab Equipment CC, South Africa Ltd. Hexadecyltriammonium bromide (HDTMA$\mathrm{Br}$ ) was purchased from Merck chemicals, South Africa. All chemicals were of analytical grade and they were used without further purification. Milli-Q water $(18.2 \mathrm{M} \Omega / \mathrm{cm})$ produced from Millipore system was used for rinsing and preparation of solutions.

\section{Synthesis of Clay Based Hybrid Sorbent}

Inorgano-organo hybrid clay based sorbent was synthesized as follows: $0.25 \mathrm{M} \mathrm{FeCl}_{3}$ and $0.25 \mathrm{M} \mathrm{MnCl}_{2} .4 \mathrm{H}_{2} \mathrm{O}$ were prepared by dissolving a known amounts of $\mathrm{FeCl}_{3}$ and $\mathrm{MnCl}_{2} \cdot 4 \mathrm{H}_{2} \mathrm{O}$ into $250 \mathrm{~mL}$ volumetric flasks. Extracts of the respective solutions were mixed at a volume ratio of $3: 1$ in $250 \mathrm{~mL}$ plastic bottle and $1 \mathrm{~g}$ of raw kaolin clay (RK) was added and soaked for $10 \mathrm{~min}$. Thereafter, $\mathrm{pH}$ of the solution was adjusted to 8.5 by adding $10 \mathrm{~mL}$ of $2 \mathrm{M} \mathrm{NaOH}$ drop wise into each of the bottles to precipitate $\mathrm{Fe}^{3+}$ and $\mathrm{Mn}^{2+}$ into their respective oxides. Thereafter, $100 \mathrm{~mL}$ of $5 \mathrm{mM}$ HDTMA-Br was added to the mixture and agitated for $60 \mathrm{~min}$ at $250 \mathrm{rpm}$ and then aged for $62 \mathrm{~h}$. After aging, the mixture was centrifuged at 3,000 rpm. Residues were washed with Milli-Q water to remove excess supernatants then oven dried for $12 \mathrm{~h}$ at $60^{\circ} \mathrm{C}$. The modified clay was then milled to pass through $250 \mu \mathrm{m}$ sieve and then stored in a zip lock plastic bag. The hybrid sorbent was then designated IOK.

\section{Characterization}

Handheld x-ray fluorescence (XRF, S1 titan 600, Bruker, Berlin, Germany) was used to determine the elemental composition, surface chemistry of the adsorbent was determined using Fourier Transform Infra-red spectrum-attenuation total reflectance (FTIR-ATR) (Bruker, Germany) at wavelength range 450 to $4,500 \mathrm{~cm}^{-1}$. The pore size distribution, pore volume and surface area were determined using Barrett Joyner Halenda (BJH) (micrometrics ASAP 2020, Norcross, GA, USA) and Brunauer Emmett Teller (BET) (micrometrics Gemini 2375, Norcross, GA, USA) models, respectively. The morphology was determined using scanning electron microscopy (SEM) (Leo1450 SEM, Voltage $10 \mathrm{kV}$, working distance $14 \mathrm{~mm}$, Ramsey, NJ, USA).

\section{Batch Experiments}

Stock solutions containing 1,000 mg/L As(III) and As(V) were prepared by dissolving an appropriate amounts of $\mathrm{AsNaO}_{2}$ and $\mathrm{HAsNa}_{2} \mathrm{O}_{4}$ in Milli-Q water $(18.2 \mathrm{M} \Omega / \mathrm{cm})$. Solutions were preserved through the addition of few drops of $3 \mathrm{M}$ $\mathrm{HNO}_{3}$. Appropriate dilutions were made from the stock solution to prepare working solutions. The adsorption kinetics were evaluated by varying time from 10 to $120 \mathrm{~min}$. Adsorbent dosage of $0.1 \mathrm{~g} / 100 \mathrm{~mL}$ and adsorbate concentration of $0.5 \mathrm{mg} / \mathrm{L}$ were used. To evaluate the adsorption isotherms, the initial concentration of $\mathrm{As}(\mathrm{III}) / \mathrm{As}(\mathrm{V})$ was varied from 0.5 to $30 \mathrm{mg} / \mathrm{L}$ and the adsorbent dosage of $0.1 \mathrm{~g} / 100 \mathrm{~mL}$ and contact time of $60 \mathrm{~min}$ were maintained. The experiment was carried out at a temperature of 298,323 , and $343 \mathrm{~K}$. The obtained data was used to evaluate the adsorption thermodynamics. The effect of initial $\mathrm{pH}$ was evaluated by varying solution $\mathrm{pH}$ from 2 to 12 using $0.01 \mathrm{M} \mathrm{NaOH}$ and $0.01 \mathrm{M} \mathrm{HCl}$ to adjust the $\mathrm{pH}$. The initial adsorbate concentration of $0.5 \mathrm{mg} / \mathrm{L}$, contact time of $60 \mathrm{~min}$ and adsorbent dosage of $0.1 \mathrm{~g} / 100 \mathrm{~mL}$ were used. The influence of coexisting ions $\left(\mathrm{F}^{-} \mathrm{Cl}^{-}, \mathrm{NO}_{3}^{-}, \mathrm{CO}_{3}^{2-}, \mathrm{SO}_{4}^{2-}, \mathrm{Mg}^{2+}\right.$, and $\left.\mathrm{Ca}^{2+}\right)$ was evaluated by spiking $5 \mathrm{mg} / \mathrm{L}$ of each co-existing ions in a solution containing $0.5 \mathrm{mg} / \mathrm{L}$ of $\mathrm{As}(\mathrm{III}) / \mathrm{As}(\mathrm{V})$. The adsorbent dosage of 
TABLE 1 | Elemental composition of RK and IOK.

\begin{tabular}{lcc}
\hline Oxides & RK (\%w/w) & IOK $(\% \mathbf{w} / \mathbf{w})$ \\
\hline $\mathrm{SiO}_{2}$ & 57.1 & 32.29 \\
$\mathrm{Al}_{2} \mathrm{O}_{3}$ & 22.05 & 8.74 \\
$\mathrm{Fe}_{2} \mathrm{O}_{3}$ & 3.88 & 9.31 \\
$\mathrm{MgO}$ & 0.57 & 0.74 \\
$\mathrm{MnO}$ & 0.02 & 1.23 \\
$\mathrm{CaO}$ & 0.95 & 0.21 \\
$\mathrm{~K}_{2} \mathrm{O}$ & 0.16 & 0.08 \\
$\mathrm{TiO}_{2}$ & 1.76 & 0.82 \\
$\mathrm{P}_{2} \mathrm{O}_{5}$ & 0.02 & 0.012 \\
\hline
\end{tabular}

$0.1 \mathrm{~g} / 100 \mathrm{~mL}$ and $60 \mathrm{~min}$ contact time were used. All experiments were conducted in triplicate and the mean values were reported. Unless otherwise stated, experiments were conducted at room temperature and initial $\mathrm{pH}$ of $6 \pm 0.5$.

\section{Adsorbent Regeneration-Reuse Cycles}

To evaluate the regeneration and reuse potential of the adsorbent, As(III)/As(V) removal experiment was conducted by treating solution containing $0.5 \mathrm{mg} / \mathrm{L} \mathrm{As}(\mathrm{III}) / \mathrm{As}(\mathrm{V})$ with $1.0 \mathrm{~g}$ of IOK at initial $\mathrm{pH}$ of 6 for $60 \mathrm{~min}$. After agitation, mixtures were filtered through $0.45 \mu \mathrm{m}$ filter membranes and the residuals of As(III) and $\mathrm{As}(\mathrm{V})$ were analyzed. Residues were washed with Milli-Q water and oven dried for $12 \mathrm{~h}$ at $60^{\circ} \mathrm{C}$ and then regenerated using $100 \mathrm{~mL}$ of $0.01 \mathrm{M} \mathrm{HCl}$ by agitating the mixture for $60 \mathrm{~min}$. The obtained residues were rinsed with excess of Milli-Q water and oven dried for $12 \mathrm{~h}$ at $60^{\circ} \mathrm{C}$. Thereafter, they were pulverized with a mortar and pestle to pass through $250 \mu \mathrm{m}$ sieve. After regeneration, $\mathrm{As}(\mathrm{III}) / \mathrm{As}(\mathrm{V})$ removal experiment was conducted as in other experiments. The regeneration-reuse cycle were continued up to 7 th cycle.

\section{Analysis of Residual Arsenic}

The residual As(III)/As(V) concentration was measured using ScTRACE Gold electrode attached to 884 professional VA Polarography (Metrohm, SA). A composite solution containing $1 \mathrm{~mol} / \mathrm{L}$ sulfamic acid, $0.5 \mathrm{~mol} / \mathrm{L}$ citric acid and $0.45 \mathrm{~mol} / \mathrm{L} \mathrm{KCl}$ was used an electrolyte. For total As concentration, $\mathrm{KMnO}_{4}$ was added as an oxidizing agent.

\section{RESULTS AND DISCUSSION}

\section{Physicochemical Characterization Elemental Composition}

Table 1 present a comparison of the elemental composition between the $\mathrm{RK}$ and IOK. It is observed that $\mathrm{SiO}_{2}$ and $\mathrm{Al}_{2} \mathrm{O}_{3}$ are major oxides the kaolin clay mineral. After modification their contents of reduced from 57.1 and $22.05 \%$ to 32.29 and $8.75 \%$, respectively. Conversely, $\mathrm{Fe}_{2} \mathrm{O}_{3}$ and $\mathrm{MnO}$ increased from 3.88 and $0.02 \%$ to 9.31 and $1.23 \%$, respectively.

\section{FTIR Analysis}

Figure 1 presents the FTIR spectrum of RK, IOK before and after arsenic removal. The bands at 3,453 and $1,645 \mathrm{~cm}^{-1}$ are

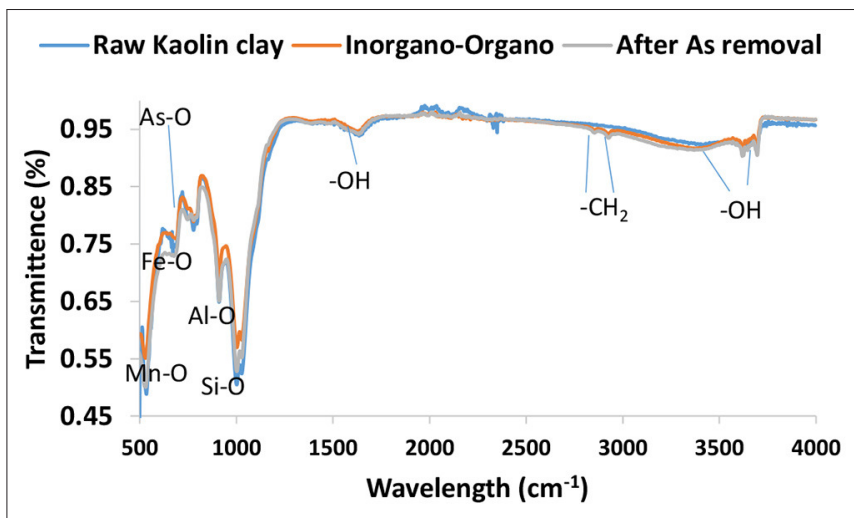

FIGURE 1 | FTIR spectrum of RK, IOK before and after arsenic adsorption.

ascribed to the vibration and stretching of hydroxyl groups and water molecules within the clay interlayers. The prominent IR peaks at wavelength region of $1,030 \mathrm{~cm}^{-1}$ could be due to the vibration of Si-O bonds. The bands at 906, 790, and 540 $\mathrm{cm}^{-1}$ could be due to the vibration of Al-O, Mn-O, and Fe-O, respectively. After modification by new bands were observed at 2,930 and $2,846 \mathrm{~cm}^{-1}$ indicating the presence of $-\mathrm{CH}_{2}$ bonds which confirm the introduction of HDTMA-Br within the clay interlayers (Thanhmingliana and Tiwari, 2015). Furthermore, the intensity of bands at 1030, 906, 790, and $540 \mathrm{~cm}^{-1}$ increased. This could be attributed to increased concentration of $\mathrm{Fe}_{2} \mathrm{O}_{3}$ and $\mathrm{MnO}$ contents as confirmed by XRF analysis. After arsenic removal a new band was observed at $778 \mathrm{~cm}^{-1}$ which could be ascribed to As-O bond. The intensity of bands at other wavelength ranges decreased after arsenic removal. This confirms the ion exchange between the hydroxyl groups in the clay interlayers and arsenic species and surface complexation between arsenic and $\mathrm{Fe}, \mathrm{Mn}, \mathrm{Al}$, and other metals in the surface of the clay minerals.

\section{Morphological Analysis}

Figure 2 presents the SEM micrographs of RK and IOK. No significant difference observed in the raw and modified kaolin clay mineral. The raw kaolin clay mineral has spongy like rough and porous surface with some irregular shapes. After modification, micrographs shows larger pores. This could be attributed to swelling and expansion of the clay interlayers during modification. The SEM-EDS spectrums of RK shows the presence of Fe, Al, Si, Mg, Ti, K Ca, and C. The spectrum of IOK showed a new peak showing Mn was observed.

\section{Surface Area Analysis}

The surface area and pore analysis are summarized in Table 2. It is noted that the total BET surface area of kaolin clay increased from 19.02 to $87.51 \mathrm{~m}^{2} / \mathrm{g}$ after modification with $\mathrm{Fe}^{3+}$ and $\mathrm{Mn}^{2+}$ polycations and HDTMA surfactant. Furthermore, the pore volume increased from 0.04 to 0.09 $\mathrm{cm}^{3} / \mathrm{g}$ after modification. The increase in surface area and pore volume could provide more active sites for sorption of ions leading to higher sorption capacity. The average pore size decreased from 9.54 to $4.68 \mathrm{~nm}$ after modification. The pore 


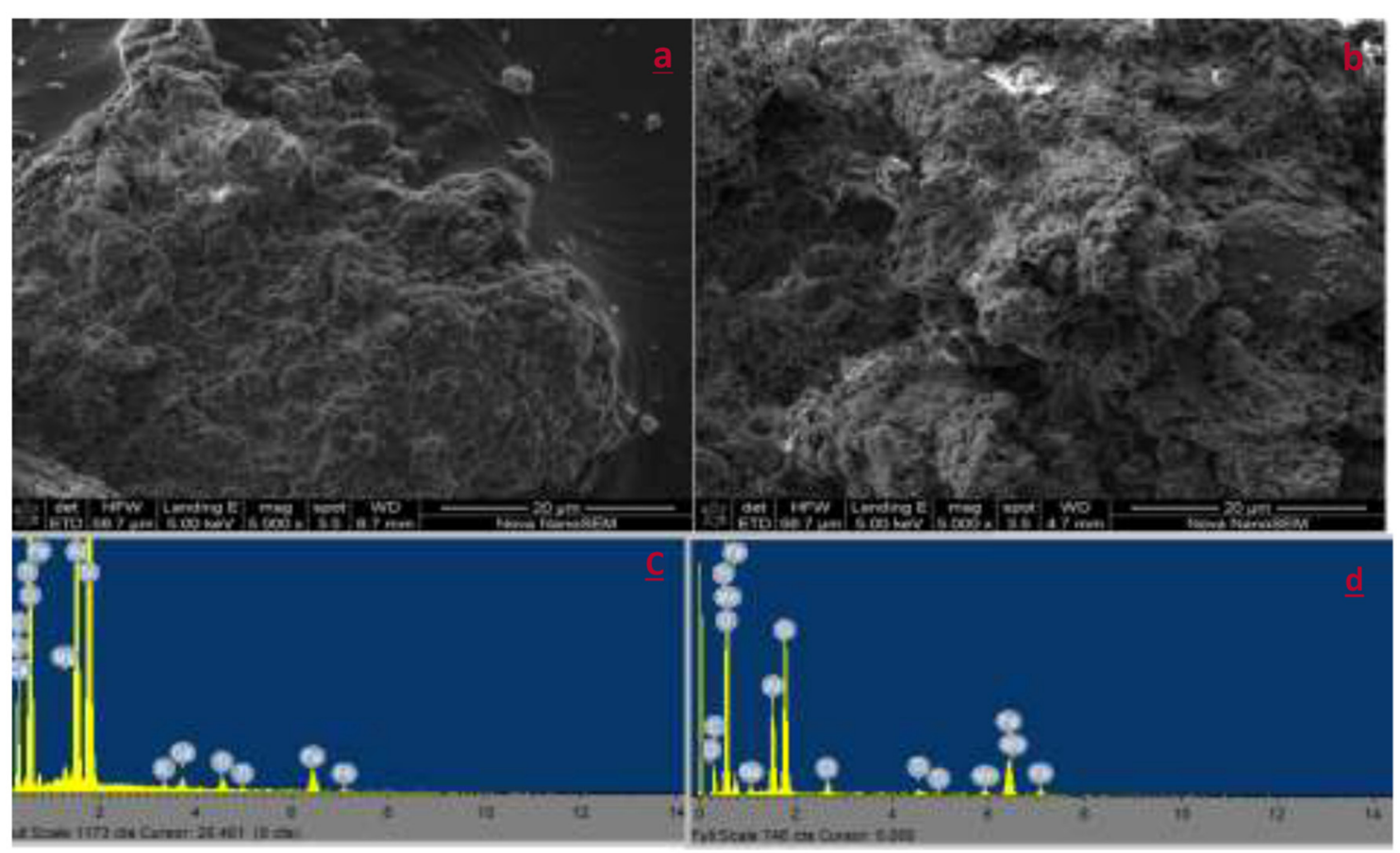

FIGURE 2 | SEM micrographs and SEM-EDS spectrum of RK $(\mathbf{a}, \mathbf{c})$ and IOK $(\mathbf{b}, \mathbf{d})$.

TABLE 2 | Surface area and pore analysis.

\begin{tabular}{|c|c|c|c|}
\hline & $\begin{array}{l}\text { Surface area } \\
\qquad\left(\mathrm{m}^{2} / \mathrm{g}\right)\end{array}$ & $\begin{array}{l}\text { Pore volume } \\
\qquad\left(\mathrm{cm}^{3} / \mathrm{g}\right)\end{array}$ & $\begin{array}{l}\text { Pore diameter } \\
\text { (nm) }\end{array}$ \\
\hline RK & 19.02 & 0.04 & 9.54 \\
\hline IOK & 87.51 & 0.09 & 4.68 \\
\hline
\end{tabular}

diameter within 2 and $50 \mathrm{~nm}$ indicates mesopore nature of the material.

\section{Batch Experiments \\ Effect of $\mathrm{pH}$}

The effect of $\mathrm{pH}$ in $\mathrm{As}(\mathrm{III})$ and $\mathrm{As}(\mathrm{V})$ removal is presented in Figure 3A. The percentage $\mathrm{As}(\mathrm{V})$ removal was optimum at $\mathrm{pH}$ between 4 and 8 while adsorption of As(III) was optimum at $\mathrm{pH}$ range 4 to 6 . Arsenic species exist in different forms under various $\mathrm{pH}$ levels and its adsorption is influences by the net surface charges. Therefore, to further elucidate the behavior of $\mathrm{As}(\mathrm{III})$ and $\mathrm{As}(\mathrm{V})$ at various $\mathrm{pH}$ levels the $\mathrm{pH}$ point of zero charge (pHpzc) of the material was determined using titration method. The results showed that the hybrid material prepared in this study has pHpzc of $8 \pm 0.5$ (Figure 3B). The material carries net positive charges at $\mathrm{pH}$ below $\mathrm{pHpzc}$ and net negative charges at $\mathrm{pH}$ above $\mathrm{pH}$ pzc. Table 3 depicts different speciation of arsenic determined using Visual MINTEQ Version 3.0 at different equilibrium $\mathrm{pH}$ levels. Therefore, the decrease in percentage arsenic removal at strong alkaline $\mathrm{pH}$ where the surface is negatively charged, could be attributed to electrostatic repulsion since both $\mathrm{As}(\mathrm{III})$ and $\mathrm{As}(\mathrm{V})$ exist as negatively charged species such as $\mathrm{HAsO}_{4}^{2-}$, $\mathrm{AsO}_{4}^{3-}, \mathrm{H}_{2} \mathrm{AsO}_{3}^{-}$, and $\mathrm{HAsO}_{3}^{2-}$. The decrease as the $\mathrm{pH}$ goes to 2 could be attributed to the fact that these species exist as neutrally charged $\mathrm{H}_{3} \mathrm{AsO}_{4}$ and $\mathrm{H}_{3} \mathrm{AsO}_{3}$ making it difficult to remove via electrostatic attraction to positively charged surface (Lee et al., 2015). Equation 1 to 5 hypothesizes the adsorption of $\mathrm{As}(\mathrm{III})$ and $\mathrm{As}(\mathrm{V})$.

$$
\begin{aligned}
\equiv \mathrm{MOH}+\mathrm{H}_{3} \mathrm{As}_{3} & \leftrightarrow \equiv \mathrm{MH}_{2} \mathrm{As}_{3}+\mathrm{H}_{2} \mathrm{O} \\
\equiv \mathrm{MOH}+\mathrm{H}_{2} \mathrm{As}_{3}^{-} & \leftrightarrow \equiv \mathrm{MHAs}_{3}^{-}+\mathrm{H}_{2} \mathrm{O} \\
\equiv \mathrm{MOH}+\mathrm{H}_{3} \mathrm{AsO}_{4} & \leftrightarrow \equiv \mathrm{MH}_{2} \mathrm{AsO}_{4}+\mathrm{H}_{2} \mathrm{O} \\
\equiv \mathrm{MOH}+\mathrm{H}_{2} \mathrm{AsO}_{4}^{-} & \leftrightarrow \equiv M \mathrm{MAsO}_{4}^{-}+\mathrm{H}_{2} \mathrm{O} \\
\equiv \mathrm{MOH}+\mathrm{HAs}_{4}^{2-} & \leftrightarrow \equiv \mathrm{MAs}_{4}^{2-}+\mathrm{H}_{2} \mathrm{O}
\end{aligned}
$$

\section{Adsorption Kinetics}

Adsorption kinetics studies were performed in order to predict the rate of adsorption and to give insight in the rate limiting factor and the adsorption mechanism. Figures $4 A, B$ presents the variation of $\mathrm{As}(\mathrm{III})$ and $\mathrm{As}(\mathrm{V})$ adsorption capacity with time. The adsorption capacity increased rapidly within the first $40 \mathrm{~min}$ and then proceed at slow rate up to 120 min suggesting that the system has reached equilibrium. The same trend was observed for arsenic species.

The pseudo first and second order of reaction kinetics models were used to predict the rate and the mechanism of As(III) and $\mathrm{As}(\mathrm{V})$ adsorption onto Inorgano-organo modified kaolin clay mineral. The mathematical representation of the models 
are depicted in equation 1 and 2, respectively (Qi et al., 2015; Munagapati and Kim, 2017).

$$
\begin{aligned}
& q_{t}=q_{e}\left(1-e^{-k_{1} t}\right) \\
& q_{t}=\frac{q_{e}^{2} k_{2} t}{1+k_{2} q_{e} t}
\end{aligned}
$$

Where $\mathrm{q}_{\mathrm{e}}$ and $\mathrm{q}_{\mathrm{t}}$ are the adsorption capacities $(\mathrm{mg} / \mathrm{g})$ of the sorbent at equilibrium and at any given time, $\mathrm{t}(\mathrm{min})$, respectively; $\mathrm{K}_{1}\left(\mathrm{~min}^{-1}\right)$ and $\mathrm{K}_{2}(\mathrm{~g} / \mathrm{mg}$. $\mathrm{min})$ are the pseudo first order and second order rate constants for adsorption processes, respectively. The initial adsorption rate, $\mathrm{h}\left(\mathrm{mg} / \mathrm{g} \cdot \mathrm{min}^{-1}\right)$ was determined based on the value of $\mathrm{qe}^{2}(\mathrm{mg} / \mathrm{g})$ and $\mathrm{K}_{2}$ (g/mg.min) from the pseudo second order model. The non-linear plots for $\mathrm{As}(\mathrm{III})$ and $\mathrm{As}(\mathrm{V})$ are presented in Figures 4A,B, respectively, while the constants parameters are presented in Table 4.
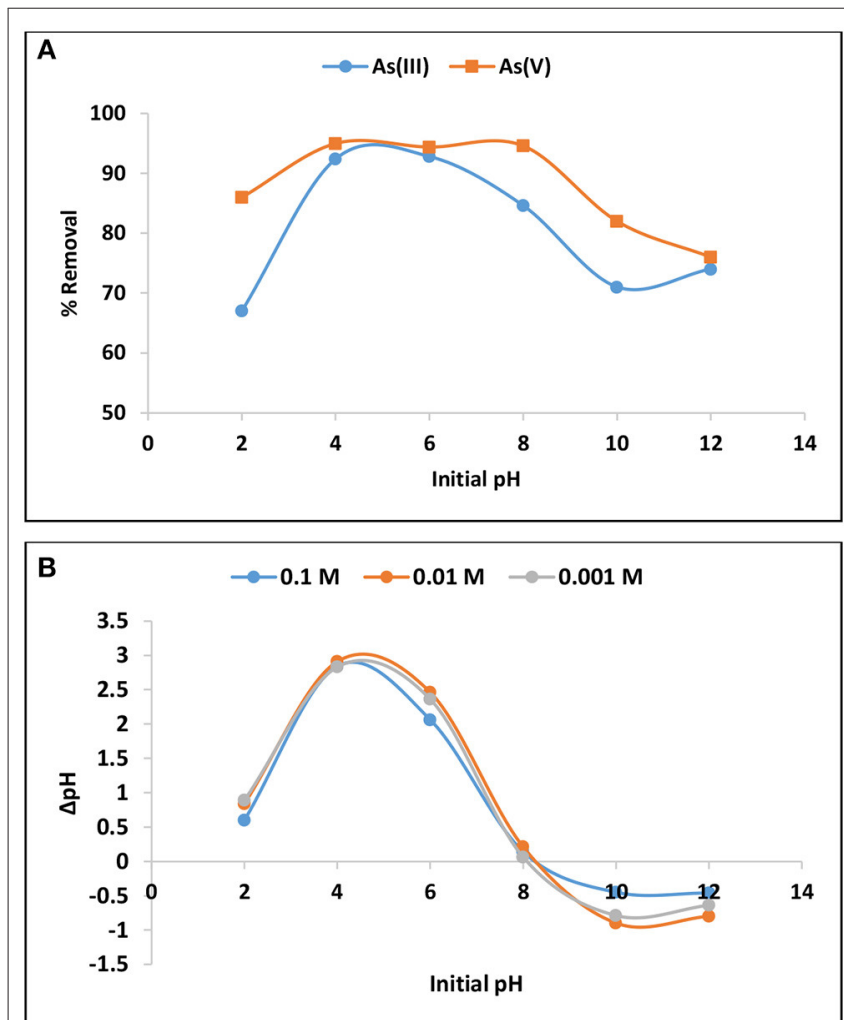

FIGURE 3 | (A) Variation of $\mathrm{As}(\mathrm{III})$ and $\mathrm{As}(\mathrm{V})$ percentage removal with initial $\mathrm{pH}$ and (B) point of zero charge (pHpzc).
The $R^{2}$-values for pseudo second order for As(III) and As(V) were found to be 0.94 and 0.98 , respectively higher than those pseudo first order $(0.70$ and 0.80$)$. The values for theoretical adsorption capacity of pseudo second order were found to be higher compared to those from pseudo first order (Table 4). This implies that the adsorption data fitted better to pseudo second order of reaction kinetics. Better fitting to pseudo second order suggests the dominance of chemisorption during the adsorption of $\mathrm{As}(\mathrm{III})$ and $\mathrm{As}(\mathrm{V})$ onto the hybrid adsorbent.

To further elucidate the rate limiting steps, the adsorption kinetics data was fitted to intra-particle diffusion model of Weber Morris (Weber and Morris, 1963). Equation (3) presents the linearized form of intra-particle diffusion model.

$$
q_{t}=k_{i} t^{0.5}+C
$$

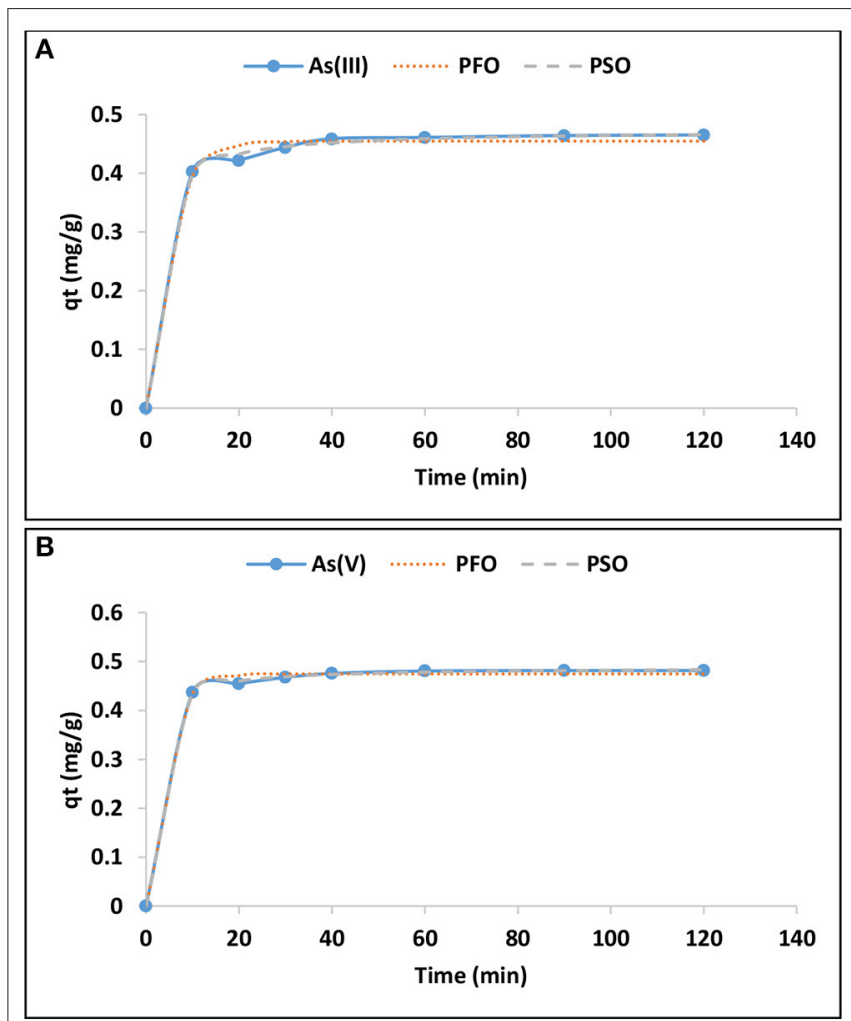

FIGURE 4 | Variation of adsorption capacity of $\mathrm{As}(\mathrm{III})$ (A) and $\mathrm{As}(\mathrm{V})$ (B) with time and adsorption kinetics $(0.1 \mathrm{~g} / 100 \mathrm{~mL}$ adsorption dosage, $0.5 \mathrm{mg} / \mathrm{L}$

\begin{tabular}{|c|c|c|c|c|c|c|c|}
\hline Eq. pH & $\mathrm{H}_{3} \mathrm{AsO}_{4}$ & $\mathrm{H}_{2} \mathrm{AsO}_{4}^{-}$ & $\mathrm{HAsO}_{4}^{2-}$ & $\mathrm{AsO}_{4}^{3-}$ & $\mathrm{H}_{3} \mathrm{AsO}_{3}$ & $\mathrm{H}_{2} \mathrm{AsO}_{3}^{-}$ & $\mathrm{HAsO}_{3}^{2-}$ \\
\hline 3.62 & 4.50 & 95.44 & 0.042 & - & 100.00 & - & - \\
\hline 6.41 & - & 78.92 & 21.07 & - & 99.82 & 0.174 & - \\
\hline 7.02 & - & 47.78 & 52.21 & - & 99.29 & 0.76 & - \\
\hline 9.46 & - & 0.32 & 99.17 & 0.47 & 33.67 & 66.31 & - \\
\hline
\end{tabular}
adsorbate concentration, $\mathrm{pH} 6.5 \pm 0.2)$.

TABLE 3 | Arsenic species at different equilibrium pH levels. 
TABLE 4 | Parameters for pseudo first and second order reactions.

\begin{tabular}{|c|c|c|c|c|c|c|c|}
\hline & \multicolumn{3}{|c|}{ Pseudo first order } & \multicolumn{4}{|c|}{ Pseudo second order } \\
\hline & $q_{e}(m g / g)$ & $\mathrm{K}_{1}\left(\min ^{-1}\right)$ & $\mathbf{R}^{2}$ & $q_{e}(m g / g)$ & $\mathrm{K}_{2}$ (g/mg.min) & $\mathrm{h}\left(\mathrm{mg} / \mathrm{g} \cdot \mathrm{min}^{-1}\right)$ & $\mathbf{R}^{2}$ \\
\hline $\operatorname{As}(I I I)$ & 0.45 & 0.20 & 0.70 & 0.47 & 1.12 & 0.26 & 0.94 \\
\hline $\mathrm{As}(\mathrm{V})$ & 0.47 & 0.24 & 0.80 & 0.48 & 1.67 & 0.38 & 0.98 \\
\hline
\end{tabular}

TABLE 5 | Constant parameters for Weber-Morris intra-particle model.

\begin{tabular}{lcccccccc}
\hline & \multicolumn{3}{c}{ Phase 1 } & & \multicolumn{3}{c}{ Phase 2 } \\
\cline { 2 - 3 } \cline { 7 - 8 } & $\mathbf{K}_{\mathbf{1}}$ & $\mathbf{C}_{\mathbf{1}}$ & $\mathbf{R}^{\mathbf{2}}$ & & $\mathbf{K}_{\mathbf{2}}$ & $\mathbf{C}_{\mathbf{2}}$ & $\mathbf{R}^{\mathbf{2}}$ \\
\hline $\operatorname{As}(\mathrm{III})$ & 0.013 & 0.39 & 0.99 & & 0.0012 & 0.47 & 0.97 \\
$\operatorname{As}(\mathrm{V})$ & 0.017 & 0.34 & 0.97 & & 0.0014 & 0.44 & 0.70
\end{tabular}

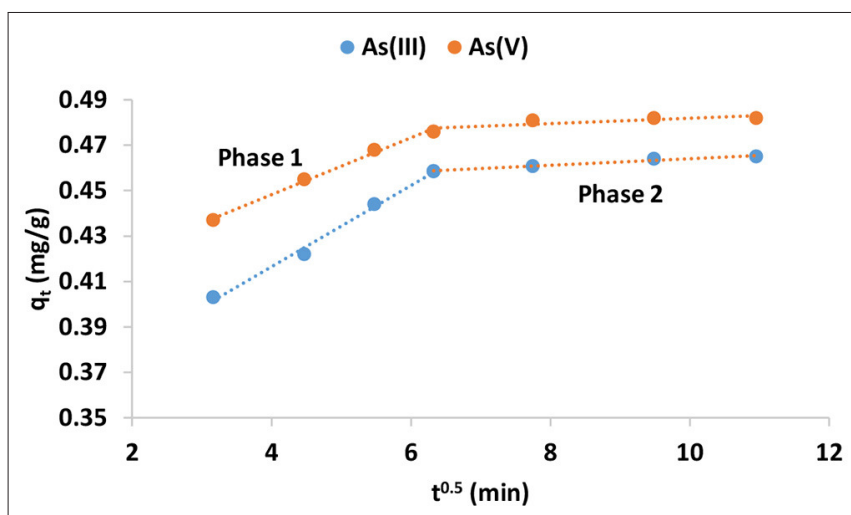

FIGURE 5 | Weber-Morris intra-particle plot for As(III) and As(N) adsorption onto IOK.

Where $\mathrm{q}_{\mathrm{t}}(\mathrm{mg} / \mathrm{g})$ is the adsorption capacity at a given time, $\mathrm{t}(\mathrm{min}) ; \mathrm{K}_{\mathrm{i}}$ is the rate of intra-particle diffusion model $\mathrm{C}$ $(\mathrm{mg} / \mathrm{g})$ is the constant associated with the thickness of the boundary layer. If the plot of $\mathrm{q}_{\mathrm{t}}$ against $\mathrm{t}^{0.5}$ is linear or passes through origin, the adsorption is solely governed by intra-particle diffusion. However, if the plot yields two or more linear plots, then adsorption is governed by both surface and intra-particle diffusion. The intra-particle plot and the constant parameters for adsorption of $\mathrm{As}(\mathrm{III})$ and $\mathrm{As}(\mathrm{V})$ is presented in Figure 5 and Table 5, respectively.

The plot (Figure 5) for both species yielded bilinear plots indicating that adsorption of As(III) and As(V) by synthesized adsorbent is a complex process involving both physical and chemical interactions between the adsorbate and the adsorbent. Ryu et al. (2017) observed the same trend during adsorption of $\mathrm{As}(\mathrm{III})$ and $\mathrm{As}(\mathrm{V})$ onto Fe-Mn modified activated carbon. Phase 1 the film diffusion leading to physiosorption wherein $\mathrm{As}(\mathrm{III})$ and $\mathrm{As}(\mathrm{V})$ ions are attracted to the boundary layer of the adsorbent through electrostatic attraction forces. Phase 2 reflects the intra-particle diffusion wherein $\mathrm{As}(\mathrm{III})$ and $\mathrm{As}(\mathrm{V})$ ions diffuse into the pores of the adsorbent leading to chemisorption. This phase involves ion exchange between the hydroxyl ions and arsenic species and weak hydrogen bonding. The rate constant for surface adsorption at phase 1 was found to be higher than the adsorption rate at phase 2 (Table 5). This suggest that intra-particle diffusion is a slower process compared to surface adsorption. This results suggest that adsorption of As(III) and $\mathrm{As}(\mathrm{V})$ is a complex process involving both surface and intraparticle diffusion.

\section{Adsorption Isotherms}

The adsorption isotherms were evaluated by varying the initial adsorbate concentration from 0.5 to $30 \mathrm{mg} / \mathrm{L}$. The experiment was conducted at 298, 323, and $343 \mathrm{~K}$. The results are presented in Figures 6A,B in terms of equilibrium concentrations against adsorption capacity. As expected, the adsorption capacity increases with increasing equilibrium As(III) and $\mathrm{As}(\mathrm{V})$ concentration. Furthermore, the adsorption capacity increased with increasing temperature. Equations (4) and (5) of Langmuir and Freundlich adsorption isotherms, respectively, were used to explain the relationship between the adsorbent and the adsorbate (Tran et al., 2016).

$$
\begin{gathered}
q_{e}=\frac{q_{\max } b C_{e}}{1+b C_{e}} \\
q_{e}=K_{f} C_{e}^{1 / n}
\end{gathered}
$$

Where $\mathrm{q}_{\mathrm{e}}(\mathrm{mg} / \mathrm{g})$ is the adsorption capacity, $\mathrm{C}_{\mathrm{e}}(\mathrm{mg} / \mathrm{L})$ is the $\mathrm{As}(\mathrm{III})$ and $\mathrm{As}(\mathrm{V})$ concentration at equilibrium, b $(\mathrm{L} / \mathrm{mg})$ and $\mathrm{q}_{\max }(\mathrm{mg} / \mathrm{g})$ are Langmuir constants related to equilibrium adsorption constant and maximum monolayer adsorption capacity. $\mathrm{K}_{\mathrm{f}}(\mathrm{mg} / \mathrm{g})$ and $1 / \mathrm{n}$ are Freundlich constant values related to adsorption capacity and adsorption intensity, respectively. The nonlinear plots of Langmuir and Freundlich isotherms are presented in Figures 6A,B for As(III) and As(V), respectively while the models constant parameters are presented in Table 6.

The adsorption isotherm data for As(III) and As(V) adsorption onto IOK was described by Langmuir isotherm model rather than Freundlich isotherm model. This suggest that the adsorption of As(III) and As(V) occurred on a monolayered surface. The maximum theoretical adsorption capacities for As(III) were found to be $7.99,9.88$, and $12.15 \mathrm{mg} / \mathrm{g}$ at 298,323 , and $343 \mathrm{~K}$, respectively while for $\mathrm{As}(\mathrm{V})$ adsorption capacities were found to be $7.32,8.36$, and $9.45 \mathrm{mg} / \mathrm{g}$ at these temperature ranges (Table 6). Conversely, the experimental adsorption capacities for As(III) at 298 and $323 \mathrm{~K}$ were found to be lower than those reported at the same temperature ranges for $\mathrm{As}(\mathrm{V})$. 


\section{Adsorption Thermodynamics}

To further elucidate the adsorption mechanisms, thermodynamics parameters such as Gibbs energy change $\left(\Delta \mathrm{G}^{\circ}\right)$, the enthalpy change $\left(\Delta \mathrm{H}^{\circ}\right)$, and the entropy $\left(\Delta \mathrm{S}^{\circ}\right)$ were determined from Equations (6) and (7) (Singh et al., 2016).

$$
\begin{array}{r}
\Delta G^{\circ}=-R T \ln K_{c} \\
\ln K_{L}=-\frac{\Delta H^{\circ}}{\Delta R T^{\circ}}+\frac{S}{R}
\end{array}
$$

Where $R$ is the molar gas constant, $8.314 \mathrm{~J}_{\mathrm{mol}}{ }^{-1} \mathrm{~K}^{-1}, \mathrm{~T}$ is the absolute temperature in Kelvin, $\Delta \mathrm{G}^{\circ}(\mathrm{KJ} / \mathrm{mol})$ is the Gibbs free energy change. $\Delta \mathrm{H}^{\circ}(\mathrm{J} / \mathrm{mol})$ is enthalpy change, $\Delta \mathrm{S}^{\circ}(\mathrm{J} / \mathrm{mol})$ is

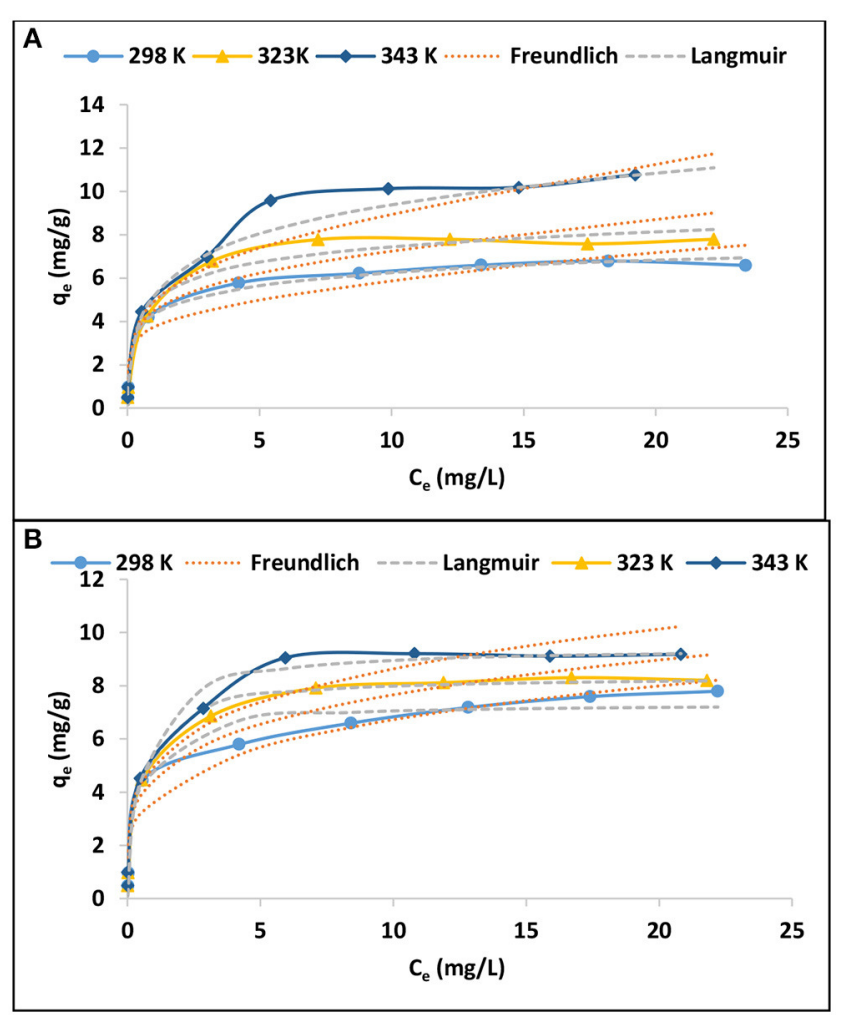

FIGURE 6 | Adsorption isotherms for (A) As(III) and (B) As(V) $(0.1 \mathrm{~g} / 100 \mathrm{~mL}$ adsorbent dosage, $0.5-30 \mathrm{mg} / \mathrm{L}$ initial concentration, 60 min contact time, $\mathrm{pH}$ $6.5 \pm 0.2)$. the change in entropy and $\mathrm{K}_{\mathrm{c}}$ is the dimensionless parameter derived from the Langmuir adsorption constant, $\mathrm{b}(\mathrm{L} / \mathrm{mg})$ by multiplying $\mathrm{b}$ by the molecular weight of the adsorbate $(\mathrm{Mw}$; $\mathrm{g} / \mathrm{mol}$ ), by 1,000 and then by 55.5 (number of moles of pure water per liter) (Tran et al., 2017). Values $\Delta \mathrm{H}^{\circ}$ and $\Delta \mathrm{S}^{\circ}$ of are determined from the slope and intercept of a plot of $\ln K_{c}$ against $1 / \mathrm{T}$ (Figure 7 ). The thermodynamic parameters are shown in Table 7.

The value of enthalpy of change $\left(\Delta \mathrm{G}^{\circ}\right)$ for the adsorption of $\mathrm{As}(\mathrm{III})$ and $\mathrm{As}(\mathrm{V})$ onto Inorgano-organo modified kaolin clay mineral was found to be negative at both initial temperatures. This suggest that adsorption of $\mathrm{As}(\mathrm{III})$ and $\mathrm{As}(\mathrm{V})$ occurred spontaneously. The $\Delta \mathrm{H}^{\circ}$ value was found to be negative which indicating exothermic nature of the adsorption process. Exothermic reactions involves both physiosorption and chemisorption processes (Tran et al., 2016). The positive value of

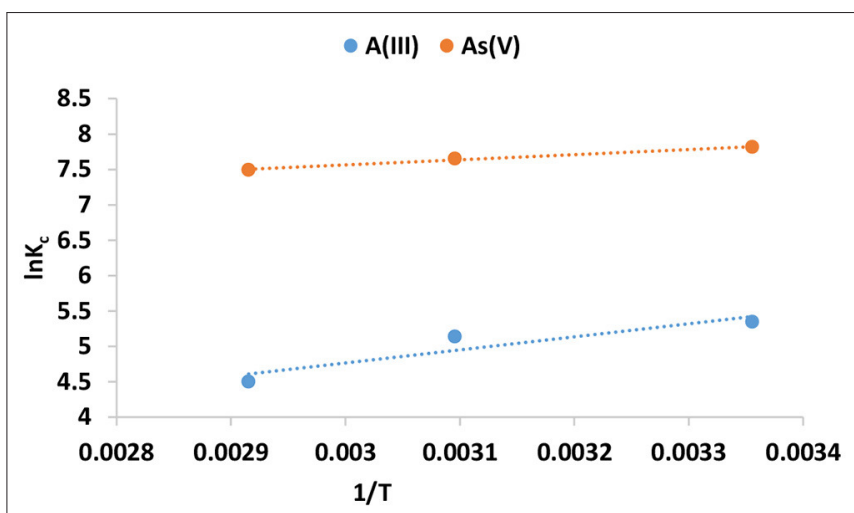

FIGURE 7 | InK $\mathrm{K}_{\mathrm{c}}$ as a function of reciprocal of adsorption temperature.

TABLE 7 | Thermodynamics parameters for As(III) and As(V) adsorption by IOK.

\begin{tabular}{cccc}
\hline & $\boldsymbol{\Delta} \mathbf{G}^{\circ}(\mathbf{K J} / \mathbf{m o l})$ & $\boldsymbol{\Delta} \mathbf{H}^{\circ}(\mathbf{K J} / \mathbf{m o l})$ & $\boldsymbol{\Delta} \mathbf{S}^{\circ}(\mathbf{J} / \mathbf{m o l})$ \\
\hline As(III) & $298 \mathrm{~K}=-13.27$ & -15.35 & 6.4 \\
& $323 \mathrm{~K}=-13.79$ & & \\
& $343 \mathrm{~K}=-12.83$ & & \\
\hline $\mathrm{As}(\mathrm{V})$ & $298 \mathrm{~K}=-19.36$ & -6.09 & \\
& $323 \mathrm{~K}=-20.54$ & & \\
& $343 \mathrm{~K}=-21.35$ & & \\
\hline
\end{tabular}

\begin{tabular}{|c|c|c|c|c|c|c|c|c|}
\hline & & \multirow[b]{2}{*}{$q_{e} \exp (m g / g)$} & \multicolumn{3}{|c|}{ Langmuir } & \multicolumn{3}{|c|}{ Freundlich } \\
\hline & & & $q_{m}(m g / g)$ & b (L/mg) & $\mathbf{R}^{2}$ & $K_{f}(m g / g)$ & $1 / n$ & $\mathbf{R}^{2}$ \\
\hline \multirow[t]{3}{*}{$\mathrm{As}(I I I)$} & $298 K$ & 6.79 & 7.99 & 0.21 & 0.98 & 1.88 & 0.4 & 0.90 \\
\hline & $323 \mathrm{~K}$ & 7.79 & 9.8 & 0.17 & 0.97 & 2.15 & 0.42 & 0.89 \\
\hline & $343 \mathrm{~K}$ & 10.77 & 12.15 & 0.09 & 0.99 & 1.96 & 0.52 & 0.95 \\
\hline \multirow[t]{3}{*}{$\mathrm{As}(\mathrm{V})$} & $298 K$ & 7.79 & 7.32 & 2.48 & 0.96 & 3.76 & 0.25 & 0.93 \\
\hline & $323 \mathrm{~K}$ & 8.2 & 8.36 & 2.10 & 0.99 & 4.52 & 0.22 & 0.93 \\
\hline & $343 \mathrm{~K}$ & 9.18 & 9.45 & 1.78 & 0.98 & 5.07 & 0.23 & 0.93 \\
\hline
\end{tabular}

TABLE 6 | Langmuir and Freundlich adsorption isotherm parameters. 
$\Delta \mathrm{S}^{\circ}$ suggest that $\mathrm{As}(\mathrm{III})$ and $\mathrm{As}(\mathrm{V})$ were randomly distributed on the surface of the adsorbent.

\section{Effect of Co-existing lons}

Figure 8 depicts the influence co-existing anions in adsorption of $\mathrm{As}(\mathrm{III})$ and $\mathrm{As}(\mathrm{V})$ by IOK. It is observed that the presence of $\mathrm{Ca}^{2+}$ and $\mathrm{Mg}^{2+}$ slightly increases the adsorption As(III)

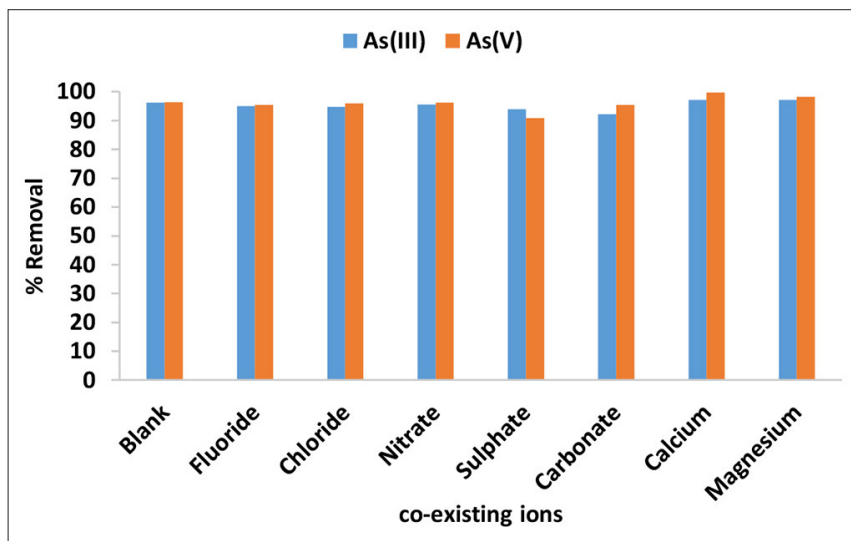

FIGURE 8 | Effect of co-existing ions in the adsorption of $A s(I I I)$ and $A s(V)$ from the solution.

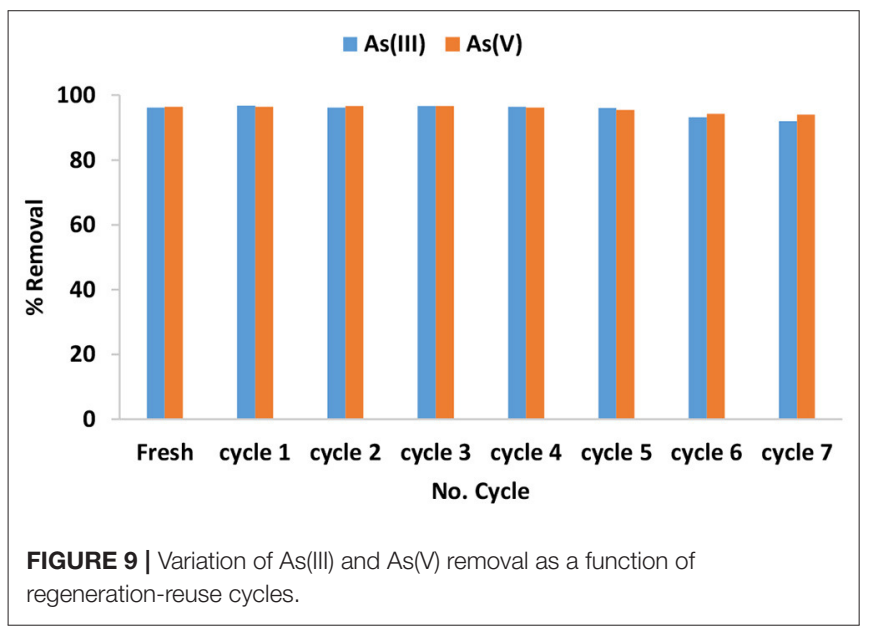

and $\mathrm{As}(\mathrm{V})$. This could be an indication that the presence of $\mathrm{Ca}^{2+}$ and $\mathrm{Mg}^{2+}$ makes the surface of the adsorbent to be more positively charged which consequently facilitate the attraction of $\mathrm{As}(\mathrm{III})$ and $\mathrm{As}(\mathrm{V})$ onto the created sorption sites (Qi et al., 2015). The presence of co-existing anions slightly inhabited the sorption As(III) and As(V). The adsorption of As(III) decreased significantly in the presence of carbonates while the adsorption of $\mathrm{As}(\mathrm{V})$ decreased significantly in the presence of sulfate. The decrease in percentage removal in the presence of anions could be attributed to competition for adsorption sites between the co-existing anions and arsenic species.

\section{Regeneration Study}

The regeneration and reuse of adsorbent was studied using $0.01 \mathrm{M} \mathrm{HCl}$ as a regenerating agent and the results for 7 successive cycles are presented in Figure 9. The percentage $\mathrm{As}(\mathrm{III})$ and $\mathrm{As}(\mathrm{V})$ removal achieved from the regeneration cycle 1 to cycle 5 was found to be $>95 \%$ which is relatively equal to the percentage removal achieved from the virgin material. This could be an indication that treatment of the adsorbent with $\mathrm{HCl}$ increases the positive sites on the surface of the material. Slight decrease as the reuse-regeneration cycles continues to 7 th cycle. The decrease could be due to inadequate regeneration of the sorption sites. This results suggests that IOK is a good material for use in arsenic removal from groundwater as it can be regenerated. The concentration of $\mathrm{Fe}$ and $\mathrm{Mn}$ were detected at trace concentrations below 0.1 $\mathrm{mg} / \mathrm{L}$ in the filtrate after 7 th cycle. Indicating that the adsorbent is stable.

\section{Comparison With Other Adsorbents}

Table 8 present the comparison for As(III) and As(V) adsorption capacities of different adsorbents reported in the literature with the maximum adsorption capacity obtained from the present study. From the table it can be noted that the maximum adsorption capacity obtained from the present study is quite higher as compared to those reported in the literature.

TABLE 8 | Comparison of adsorption capacities.

\begin{tabular}{|c|c|c|c|c|}
\hline Adsorbent & Experimental conditions & $\mathrm{q}_{\mathrm{e}} \mathrm{As}(\mathrm{III})(\mathrm{mg} / \mathrm{g})$ & $q_{e} A s(V)(m g / g)$ & References \\
\hline HDTMA-Al-bentonite & $\begin{array}{l}\text { Initial concentration:2-18 mg/; Adsorbent dosage: } 2 \mathrm{~g} / \mathrm{L} ; \mathrm{pH} \text { : } \\
4.5\end{array}$ & 2.24 & 8.93 & Lee et al., 2015 \\
\hline Iron impregnated charred GAP & $\begin{array}{l}\text { Initial concentration: 0.05-200 mg/L; Adsorbent dosage: } 0.5 \\
\text { g/100 mL; pH:7 }\end{array}$ & 3.25 & 5.09 & Yin et al., 2017 \\
\hline $\begin{array}{l}\text { Aluminum pillared HDTMA } \\
\text { sericite }\end{array}$ & $\begin{array}{l}\text { Initial concentration: } 1 \text { to } 20 \text { mg/L; adsorbent dosage: } 0.2 \\
\text { g/100 mL; } \mathrm{pH} 4.5 \text {. }\end{array}$ & 0.40 & 0.46 & $\begin{array}{l}\text { Tiwari and Lee, } \\
2012\end{array}$ \\
\hline CTMAB-Fe-Montmorillonite & $\begin{array}{l}\text { Initial concentration: 1-60 mg/L; adsorbent dosage: } 0.1 \\
\text { g/25 mL; pH } 6.5\end{array}$ & 11.36 & 8.85 & Ren et al., 2014 \\
\hline Fe/Mn-HDTMA kaolin & $\begin{array}{l}\text { Initial concentration: 0.5-30 mg/L; adsorbent dosage; } 0.1 \\
\text { g/100 mL; pH:6.5 } \pm \text { 0.5, Temp: } 298 \mathrm{~K}\end{array}$ & 7.99 & 7.32 & This study \\
\hline
\end{tabular}




\section{CONCLUSION}

A clay based hybrid adsorbent for As(III) and As(V) was successfully synthesized through intercalation of Fe-Mn oxides and HDTMA-Br. Batch experiments showed that As(III) removal was optimum at $\mathrm{pH}$ range of 4-6 while the $\mathrm{As}(\mathrm{V})$ removal was optimum at $\mathrm{pH}$ range $4-8$. The adsorption data for both species of arsenic fitted better to pseudo second order of reaction kinetics which suggest that the dominant adsorption mechanism was chemisorption. The isotherm studies showed that the data fitted better to Langmuir isotherm model as compared to Freundlich model indicating that adsorption of both $\mathrm{As}(\mathrm{III})$ and $\mathrm{As}(\mathrm{V})$ occurred on a monolayered surface. The maximum adsorption $\mathrm{As}(\mathrm{III})$ and $\mathrm{As}(\mathrm{V})$ capacity at room temperature as determined by Langmuir model were found to be 7.99 and $7.32 \mathrm{mg} / \mathrm{g}$, respectively. The thermodynamic studies for sorption of As(III) and $\mathrm{As}(\mathrm{V})$ showed that values of $\Delta \mathrm{G}^{\circ}$ and $\Delta \mathrm{H}^{\circ}$ were negative indicating that adsorption process occurred spontaneously and is exothermic in nature. The regeneration study showed that the inorgano-organo modified kaolin clay mineral can be reused for up 7 adsorption-regeneration cycles using $0.01 \mathrm{M} \mathrm{HCl}$ as a

\section{REFERENCES}

Bardach, A. E., Ciapponi, A., Soto, N., Chaparro, M. R., Calderon, M., Briatore, A., et al. (2015). Epidemiology of chronic disease related to arsenic in Argentina: a systematic review. Sci. Total Environ. 538, 802-816. doi: 10.1016/j.scitotenv.2015.08.070

Bhattacharyya, K. G., and Gupta, S. S. (2008). Adsorption of a few heavy metals on natural and modified kaolinite and montmorillonite: a review. Adv. Coll. Interf. Sci. 140, 114-131. doi: 10.1016/j.cis.2007. 12.008

Bhowmick, S., Pramanik, S., Singh, P., Mondal, P., Chatterjee, D., and Nriagu, J. (2018). Arsenic in groundwater ofWest Bengal, India: a review of human health risks and assessment of possible intervention options. Sci. Total Environ. 612, 148-169. doi: 10.1016/j.scitotenv.2017.08.216

Duker, A. A., Carranza, E. J. M., and Hale, M. (2005). Arsenic geochemistry and health. Environ. Int. 31, 631-641. doi: 10.1016/j.envint.2004. 10.020

Ghosh, S., Debsarkar, A., and Dutta, A. (2019). Technology alternatives for decontamination of arsenic rich groundwater-a critical review. Environ. Technol. Innovat. 13, 277-303. doi: 10.1016/j.eti.2018.12.003

Gitari, W., and Mudzielwana, R. (2018). Mineralogical and Chemical Characteristics of Raw and Modified Clays and Their Application in Arsenic and Fluoride Removal: Review, Current T Zoveidavianpoor opics in the Utilization of Clay in Industrial and Medical Applications, Mansoor Zoveidavianpoor. IntechOpen. doi: 10.5772/intechopen.74474

Lee, S. M., Lalhmunsiama, Thanhmingliana, and Tiwari, D. (2015). Porous hybrid materials in the remediation of water contaminated with As(III) and As(V). Chem. Eng. J. 270, 496-507 doi: 10.1016/j.cej.2015. 02.053

Mishra, T., and Mahato, D. K. (2016). A comparative study on enhanced $\operatorname{arsenic}(\mathrm{V})$ and arsenic(III) removal by iron oxide and manganese oxide pillared clays from ground water. J. Environ. Chem. Eng. 4, 1224-1230. doi: 10.1016/j.jece.2016.01.022

Munagapati, V. S., and Kim, D. S. (2017). Equilibrium isotherms, kinetics, and thermodynamics studies for congo red adsorption using calcium alginate beads impregnated with nano-goethite. Ecotoxicol. Environ. Safety 141, 226-234. doi: 10.1016/j.ecoenv.2017.03.036

Qi, J., Zhang, G., and Li, H. (2015). Efficient removal of arsenic from water using a granular adsorbent: Fe-Mn binary oxide impregnated chitosan bead. Bioresour Technol. 193, 243-249. doi: 10.1016/j.biortech.2015.06.102 regenerant. This findings showed that IOK developed in this study is suitable for use in removal of arsenic from groundwater.

\section{DATA AVAILABILITY STATEMENT}

All datasets generated for this study are included in the article/supplementary material.

\section{AUTHOR CONTRIBUTIONS}

RM designed and conducted the experiments, and also wrote the draft manuscript. MG made conceptual contribution, supervised the work, and edited the draft manuscript. PN made the conceptual contribution, made suggestions on the manuscript and supervised the work.

\section{ACKNOWLEDGMENTS}

Authors would like to acknowledge financial support from NRF, Saif, and University of Venda RPC grant Number: SES/17/ERM/03, TESPESKOM grant.

Ren, X., Zhang, Z., Luo, H., Hu, B., Dang, Z., Yang, C., et al. (2014). Adsorption of arsenic on modified montmorillonite. Appl. Clay Sci. 97-98, 17-23. doi: 10.1016/j.clay.2014.05.028

Ryu, S. R., Jeom, E. K., Yang, J. S., and Baek, K. (2017). Adsorption of $\mathrm{As}(\mathrm{III})$ and $\mathrm{As}(\mathrm{V})$ in groundwater by $\mathrm{Fe}-\mathrm{Mn}$ binary oxide-impregnated granular activated carbon (IMIGAC). J. Taiwan Inst. Chem. Eng. 72, 62-69. doi: 10.1016/j.jtice.2017.01.004

Singh, M., Dosanjhm, H. S., and Singh, H. (2016). Surface modified spinel cobalt ferrite nanoparticles for cationic dye removal: kinetics and thermodynamics studies. J. Water Process Eng. 11, 152-161. doi: 10.1016/j.jwpe.2016. 05.006

Smedley, P. L., and Kinniburgh, D. G. (2002). A review of the source, behaviour and distribution of arsenic in natural waters. Appl. Geochem. 17, 517-568. doi: 10.1016/S0883-2927(02)00018-5

Su, J., Huang, H. G., Jin, X. Y., Lu, X. Q., and Chen, Z. L. (2011). Synthesis, characterization and kinetic of a surfactant-modified bentonite used to remove As(III) and As(V) from aqueous solution. J. Hazard. Mater. 185, 63-70. doi: 10.1016/j.jhazmat.2010.08.122

Thanhmingliana and Tiwari, D. (2015). Efficient use of hybrid materials in the remediation of aquatic environment contaminated with micro-pollutant diclofenac sodium. Chem. Eng. J. 263, 364-373. doi: 10.1016/j.cej.2014. 10.102

Tiwari, D., and Lee, S. M. (2012). Novel hybrid materials in the remediation of ground waters contaminated with As(III) and As(V). Chem. Eng. J. 204-206, 23-31. doi: 10.1016/j.cej.2012.07.086

Tran, H. N., You, S. J., and Chao, H. P. (2016). Thermodynamic parameters of cadmium adsorption onto orange peel calculated from various methods: a comparison study. J. Environ. Chem. Eng. 4, 2671-2682. doi: 10.1016/j.jece.2016.05.009

Tran, H. N., You, S. J., Hosseini-Bandegharaei, A., and Chao, H. P. (2017). Mistakes and inconsistencies regarding adsorption of contaminants from aqueous solutions: a critical review. Water Res. 120, 88-116. doi: 10.1016/j.watres.2017.04.014

Weber, W. J., and Morris, J. C. (1963). Kinetics of adsorption on carbon from solution. J. Sanit. Eng. Div. 89, 31-60.

WHO (2017). World Health Organization. Guidelines for Drinking-Water Quality: Fourth Edition Incorporating the First Addendum. Geneva: Licence: CC BY-NCSA 3.0 IGO.

Yin, H., Kong, M., Gu, X., and Chen, H. (2017). Removal of arsenic from water by porous charred granulated attapulgite-supported hydrated 
iron oxide in bath and column modes. J. Clean. Product. 166, 88-97. doi: 10.1016/j.jclepro.2017.08.026

Zhang, G., Liu, H., Qu, J., and Jefferson, W. (2012). Arsenate uptake and arsenite simultaneous sorption and oxidation by $\mathrm{Fe}-\mathrm{Mn}$ binary oxides: Influence of $\mathrm{Mn} / \mathrm{Fe}$ ratio, $\mathrm{pH}, \mathrm{Ca}^{2+}$, and humic acid. J. Colloid Interf. Sci. 366, 141-146. doi: 10.1016/j.jcis.2011.09.058

Zhang, L., Qin, X., Tang, J., Liu, W., and Yang, H. (2017). Review of arsenic geochemical characteristics and its significance on arsenic pollution studies in karst groundwater, Southwest China. Appl. Geochem. 77, 80-88. doi: 10.1016/j.apgeochem.2016. 05.014
Conflict of Interest: The authors declare that the research was conducted in the absence of any commercial or financial relationships that could be construed as a potential conflict of interest.

Copyright (c) 2020 Mudzielwana, Gitari and Ndungu. This is an open-access article distributed under the terms of the Creative Commons Attribution License (CC BY). The use, distribution or reproduction in other forums is permitted, provided the original author(s) and the copyright owner(s) are credited and that the original publication in this journal is cited, in accordance with accepted academic practice. No use, distribution or reproduction is permitted which does not comply with these terms. 